\title{
Batymetrické měření pro stanovení morfologie dna vodní nádrže
}

\section{ŠTĚPÁN MARVAL, TOMÁŠ HEJDUK, KLÁRA DUŠKOVÁ, MARTIN TOMEK, TOMÁŠ VYBíRAL, RADEK ROUB, YVETTA VELÍSKOVÁ, VALENTÍN SOČUVKA, PETR DUŠEK, JIŘí HLAVÁČEK}

\author{
Klíčová slova: sediment - batymetrické měření - EcoMapper - RiverSurveyor M9
}

\section{SOUHRN}

Informační a komunikační technologie jsou v současné době jedním z rozhodujících faktorů ovlivňujících ekonomický a společenský vývoj. Obdobný vývoj a trendy ve vazbě na informační a komunikační technologie Ize zaznamenat i v oboru vodního hospodářství. Pro získání relevantních výsledků v oblasti říční hydrauliky, stanovení kapacit vodních toků a nádrží, sledování množství a dynamiky sedimentů jsou rozhodující vstupní data. Příspěvek prezentuje souhrn výsledků a zkušeností z prováděných batymetrických měření na vodárenské nádrži (VN) Nýrsko na Úhlavě. V rámci pilotní monitorovací kampaně byla získána data o morfologii dna vodní nádrže pomocí sofistikovaného prístrojového vybavení na bázi echo sounderu RiverSurveyor M9 a EcoMapper AUV (z angl. Autonomous Underwater Vehicle). $V$ príspěvku je uvedena príprava a postup terénního měření, popis následného postprocesingu získaných datových sad, vzájemné srovnávací analýzy, včetně porovnání s datovými sadami pořízenými pomocí ultrazvukové měřicí aparatury firmy Meridata ty MD500 osazené na měřicím člunu Joska, který je provozován Povodím Vltavy, s. p.

\section{ÚVOD}

Procesy eroze na zemědělské půdě a s tím spojená sedimentace ve vodních nádržích jsou aktuálně jedním z největších globálních vodohospodářských problémů [1-4]. Po celém světě mají procesy eroze, transportu půdních částic a sedimentace významný dopad na environmentální, ekonomickou i sociální sféru. Více než padesát procent původní zásobní kapacity světových nádrží bude pravděpodobně ztraceno v průběhu následujících třiceti let kvưli sedimentaci [5].

Zanášení vodních toků a nádrží produkty eroze způsobuje především zmenšení průtočnosti koryt vodních toků, akumulačních prostorů vodních nádrží a ovlivňuje jejich hydraulickou funkci, kdy se zkracuje doba zdržení, zvyšuje se rychlost průtoku nádrží a snižuje se zabezpečenost odběru vody. Obecně tím dochází ke snížení objemu zadržené vody v území, což přináší dopady i na jakostní ukazatele vody. Při nižším objemu vody v nádržích dochází k rychlejšímu zvyšování teploty, což v kombinaci s uvolňujícími se živinami ze sedimentů významně podporuje eutrofizační procesy. Transport sedimentů do nádrže a rychlost sedimentace závisí na mnoha faktorech. Jsou jimi množství a distribuce srážek, rozmístění a typ vegetačního pokryvu, velikost povodí, geologické a geomorfologické poměry ve sběrné oblasti i míra antropogenních zásahů do krajiny [6, 7].

Pro detailní geomorfologické analýzy povodí jsou rozhodující kvalitní vstupní data. Metodou leteckého laserového skenování (LLS) je možné získávat velké množství bodových dat s georeferenčními informacemi $(X, Y, H)$ ve velmi

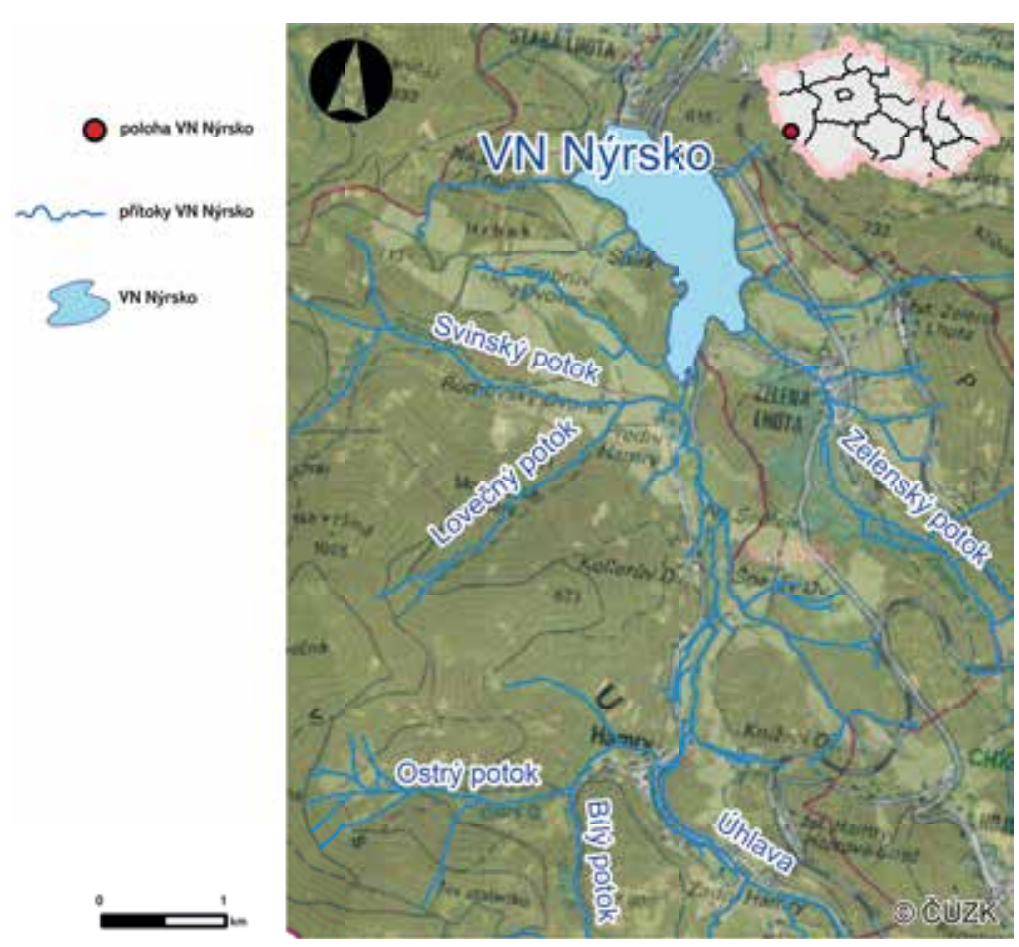

Obr. 1. Pilotní lokalita - VN Nýrsko

Fig. 1. Pilot site Nýrsko water reservoir

krátkém časovém intervalu. Ve spojení s poměrně vysokým stupněm automatizace jejich zpracování při vytváření digitálního modelu terénu a povrchu představuje jednu z nejefektivnějších metod pro získávání relevantních prostorových dat. V roce 2013 bylo dokončeno nové výškopisné mapování metodou leteckého laserového skenování území České republiky (ČR), které poskytlo nové výškopisné produkty Digitální model reliéfu 4. generace (DMR 4G), Digitální model reliéfu 5. generace (DMR 5G) a Digitální model povrchu 1. generace (DMP 1G) [8,9]. Otázkou přesto zůstává, co se nachází pod vodní hladinou, jaké jsou zásobní (retenční) kapacity vodních toků, vodních nádrží. Kolik máme sedimentů ve vodních tocích či vodních nádržích, jaká je jejich dynamika. Na tyto otázky hledá odpovědi vědní obor batymetrie.

Na počátku batymetrických měření hloubek byla použivána olovnice. Dnes je jednou z nejmodernějších a nejpouživanějších metod pro získání informace o morfologii dna vodních nádrží technologie sonaru (SOund Navigation And Ranging) v kombinaci s metodou určení polohy GNSS-RTK (Global Navigation Satellite System - Real Time Kinematic). Na VN Nýrsko byla touto technologií 
v roce 2017 provedena testovací měřicí kampaň za účelem získání poznatků o morfologii dna. Pro zaměření vodárenské nádrže Nýrsko byla mimo jiné využita měřicí aparatura EcoMapper, která byla na území ČR testována poprvé. Pro doměření v blízkosti břehové linie a v oblasti sedimentačního kuželu zde byly využity dvě měrící aparatury RiverSurveyor M9, které byly neseny na míru sestrojeným trimaranem na dálkové ovládání a originálním plavidlem Hydroboard II.

AUV prístroje byly pưvodně vyvíjeny především pro vojenské účely, $v$ současnosti představují zařízení, která se využívají v široké škále hydrografického průzkumu. První pokusy o sestrojení AUV prístroje proběhly v roce 1957 na univerzitě ve Washingtonu. Pomocí prvních sestrojených AUV se zkoumala difúze, zvukový přenos a výzkum pohybu ve vodě. $V$ průběhu 80 . let minulého století se pak AUV přístroje začaly používat také na průzkumné a hydrografické účely [10].

Získáním digitálního modelu reliéfu (DMR), který bude reflektovat i požadovanou informaci o morfologii vodního dna, je možné analyzovat zásobní kapacity vodních toků a nádrží. Při využití optimálního postupu je možné kvantifikovat množství sedimentů ve vodních tocích či nádržích, sledovat jejich dynamiku, resp. identifikovat kritické body vstupu sedimentů do vodních toků a nádrží (tvorba sedimentačních kuželů) a v důsledku toho príijímat příslušná opatření, která množství deponovaných sedimentů ve vodních tocích a nádržích omezí.

\section{METODIKA SBĚRU DAT, PRŮBĚHU MĚŘENÍ A ZPRACOVÁNÍ DAT}

\section{Pilotní lokalita}

Vodní nádrž Nýrsko se nachází na úpatí Šumavy na horním toku Úhlavy nad obcí Nýrsko, viz obr. 1 a 2. Stavba přehrady probíhala v letech 1965-1969. Hlavním účelem stavby je akumulace vody pro vodárenské účely. Vodní nádrž Nýrsko poskytuje pitnou vodu v oblasti Plzeňska, Klatovska a Domažlicka. Vzdušní líc je osázen stabilizačními dřevinami, přičemž vodní dílo dobře zapadá do okolní krajiny. Délka hráze v koruně je 320 m a výška nad terénem 36,2 m. Při levém břehu prochází hrází odpadní a komunikační štola, na jejímž začátku stojí kruhová věž sdruženého objektu, ve kterém je šachtový přeliv, dvě spodní výpusti a vodárenské odběry. Plocha povodí VN Nýrsko se rozkládá na 80,9 km², délka vzdutí je 2,5km, zatopená plocha činí 148 ha a objem je stanovený na 20,75 mil. m³. Nádrž se nachází v III. zóně chráněné krajinné oblasti Šumava.

\section{Měřicí aparatura}

Měřicí aparatura EcoMapper byla navržena tak, aby umožňovala rychlý sběr hloubkových dat, kvalitativních parametrů vody a detekci objektů pomocí side-scan sonaru (obr. 3). EcoMapper představuje př́stroj, který je schopný samostatně se pohybovat po volné hladině nebo pod jejím povrchem v předem stanovené hloubce a vykonávat sofistikovaný záznam definovaných dat.

Zařízení EcoMapper je tvořeno vysokovýkonným hardwarovým vybavením $\checkmark$ kombinaci se sofistikovaným softwarem [11].

Z hlediska konstrukčního je EcoMapper tvořen třemi hlavními částmi. $\checkmark$ prední sekci jsou umístěné senzory, které slouží k měření kvalitativních parametrů vody ( $\mathrm{pH}$, teplota, chlorofyl aj.), tlakový senzor a DVL senzor (Dopler Velocity Log), sloužící pro navigaci zařízení při misích pod vodní hladinou. Ve střední části zařízení jsou umístěny elektronické komponenty, baterie a integrovaná palubní jednotka. V zadní sekci je pak umístěný lodní šroub zajištující pohyb zařízení a GPS anténa, která slouží pro navigaci v prípadě měření na hladině [11].

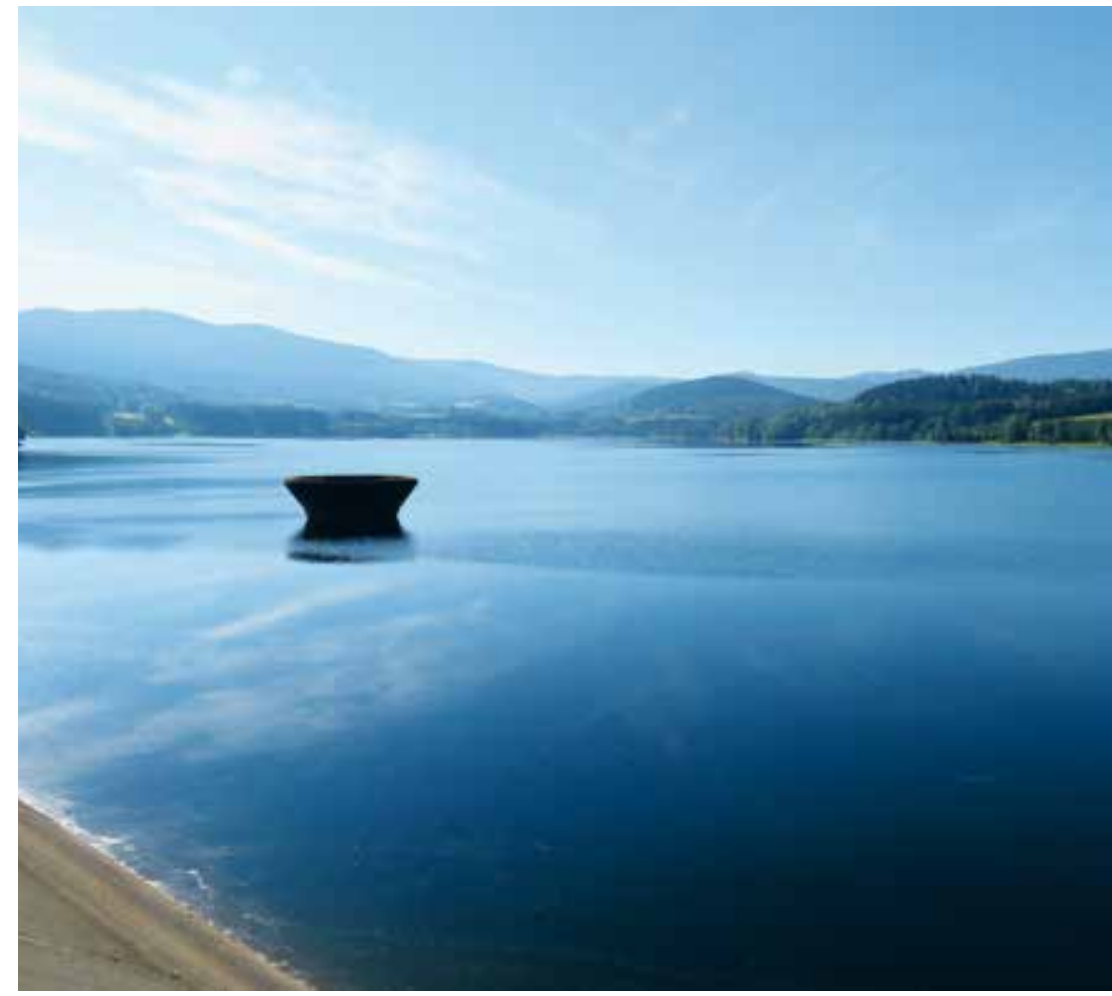

Obr. 2. Pilotní lokalita - VN Nýrsko, pohled jižně z tělesa hráze

Fig. 2. Pilot site Nýrsko water reservoir, a view south of the dyke body

EcoMapper po dobu měření shromažduje data předem stanovených parametrů v sekundových intervalech, ke kterým automaticky přidává lokalizační data. Pro měření batymetrie je možné využít tzv. bottom tracking (více-paprsčitý sonar) nebo single beam (jedno-paprsčitý sonar). Konkrétní možnosti nastavení a specifikaci hardwarových součástí detailně popisuje dokument viz [12].

Pro účely porovnání presesnosti získaných dat byla část VN Nýrsko v blízkosti hlavního př́toku (Úhlava) a v oblasti břehové linie zaměřena př́stroji na bázi sonaru RiverSurveyor M9. Jedná se o zařizení, která primárně slouží pro měření průtoku na základě Dopplerova jevu - Acoustic Doppler Current Profiler (ADCP). RiverSurveyor M9 však představuje robustní zařizení, které je možné využít i v prípadě měření batymetrie v rozsahu hloubek 0,2-80 m [13], což odpovídá hodnotám zaznamenaným při kampani na VN Nýrsko. Při instalaci této aparatury na poloautomatickém plavidle trimaran zde byla zaznamenána batymetrická data od $18 \mathrm{~cm}$. Měricí aparatura je velmi sofistikovaným zařízením kombinujícím ověrenou instrumentaci ADCP se softwarem pro osobní počítač nebo mobilní telefon. Přístrojové vybavení bylo testováno s velkou mírou přesnosti [14] a jeho kompletní specifikaci a možnosti využití popisuje dokument viz [13]

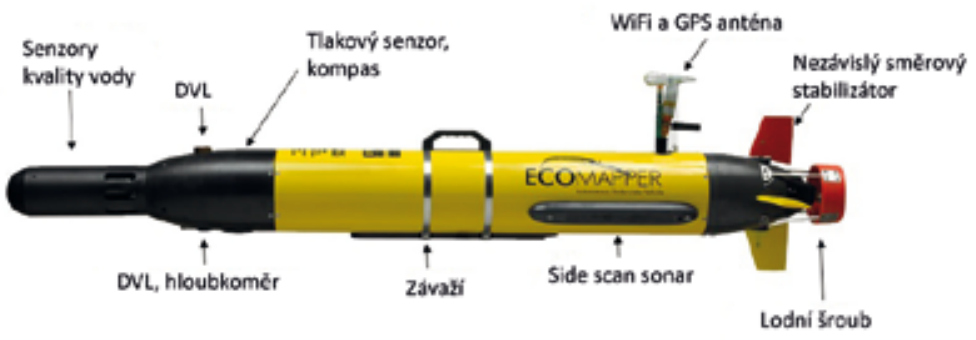

Obr. 3. Konstrukční provedení EcoMapper

Fig. 3. EcoMapper design 
Pro potřeby měření na VN Nýrsko bylo první zařízení RiverSurveyor M9 připevněno na nosném plavidle, konstruovaném do podoby trimaranu, tj. nosné lodě disponující trupem lodi a dvěma stabilizačními plováky. Konstrukce trimaranu pro batymetrická měěení vychází z požadavku na rychlost pořizování dat a stabilitu nosného plavidla, přičemž splňuje požadavek na poloautomatické měřicí zařízení, viz obr. 4 [15]. Druhé zařízení RiverSurveyor M9 bylo při měřicí kampani připevněno na originálním nosném plavidle Hydroboard II (obr. 5) dodávaném firmou SonTek. Toto plavidlo nedisponuje vlastním pohonem, proto je nutné jej při batymetrickém měření umístit za tažné plavidlo, v našem případě nafukovací člun s elektromotorem. Kompletní měřicí vybavení použité na lokalitě VN Nýrsko je prezentováno na obr. 6.

\section{Př́prava a průběh měření}

Měřická kampaň byla provedena 2.-3. srpna v roce 2017 v př́iznivých meteorologických podmínkách, kdy nejvyšší teploty dosahovaly $26-30{ }^{\circ} \mathrm{C}$ a vanul mírný západní vítr o síle 3-7 m.s.-1, který k večeru ustával. Vzhledem k vodárenským

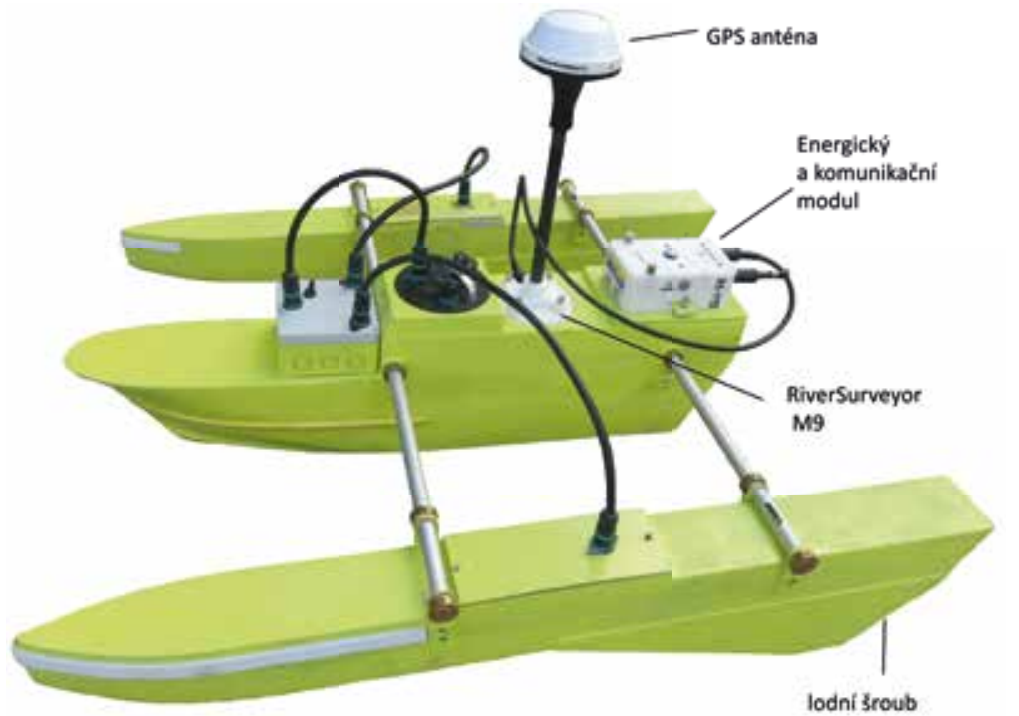

Obr. 4. Konstrukční provedení plavidla trimaran

Fig. 4. Trimaran design

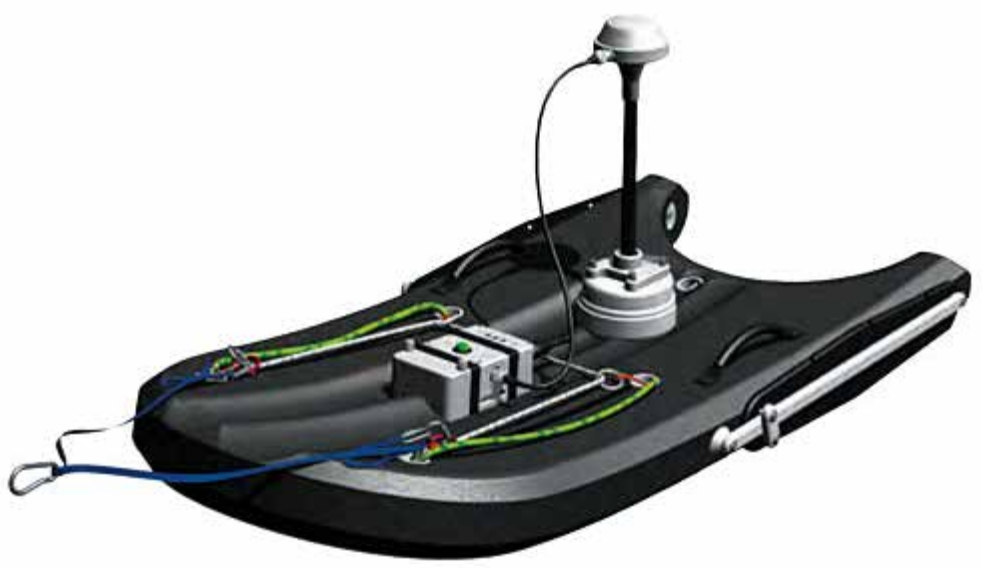

Obr. 5. Konstrukční provedení plavidla Hydroboard II [16]

Fig. 5. Hydroboard II design [16] účelům nádrže bylo nutné před samotnou měřickou kampaní žádat o povolení vstupu na území VN Nýrsko na vodoprávním úřadu Klatovy. Po specifikaci účelu, délky pobytu a využití získaných poznatků bylo žádosti bez větších obtiží vyhověno a vlastní hydrografický výzkum mohl proběhnout.

Sběr dat pomocí prístrojového vybavení EcoMapper funguje na principu sledování předem připravené trasy tzv. mise, která je vytvářená v softwarovém prostředí VectorMap. Plánování mise zahrnuje nastavení navigačních bodů, jejich vzájemné vzdálenosti, hloubku ponoru, rychlost měření, nastavení konkrétních kvalitativních parametrů a bezpečnostních opatření. Po spuštění mise EcoMapper pracuje nezávisle na uživateli a pro navigaci využívá integrovaný systém GPS s korekcemi EGNOS (European Geostationary Navigation Overlay Service). V průběhu jednotlivých misí EcoMapper sleduje trasu podle předem naprogramovaných bodů (waypointů). Po dokončení své mise EcoMapper využívá pro komunikaci vzdálené připojení plochy, které slouží na odesílání zaznamenaných dat přes bezdrátové Wi-Fi připojení a bezpečné ukončení mise [17].

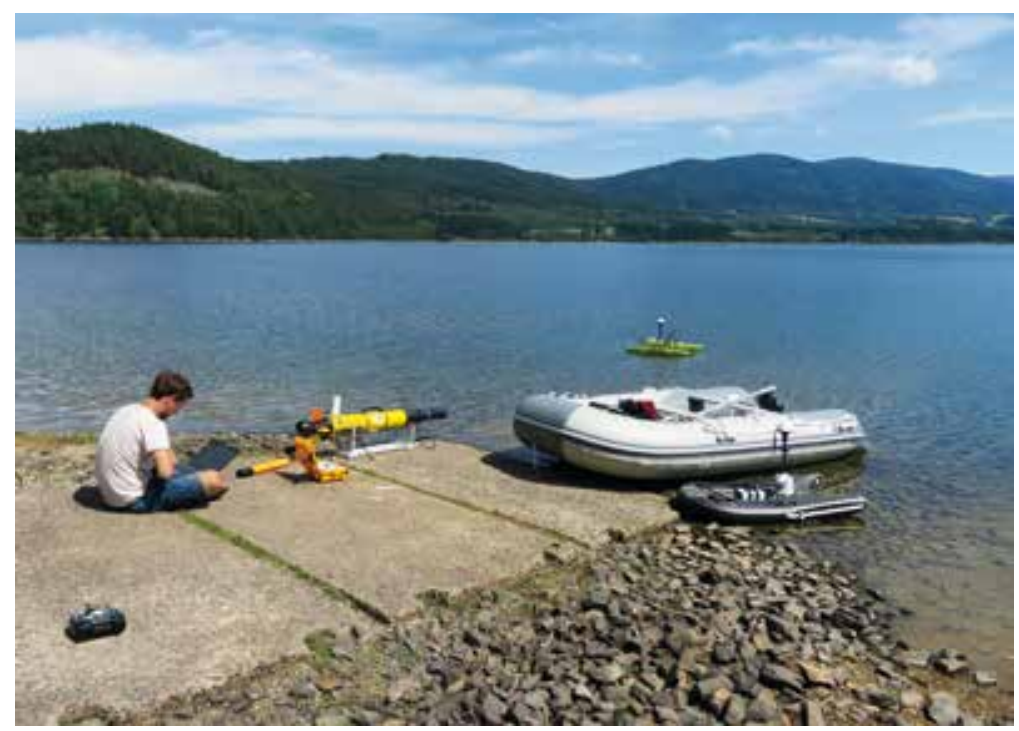

Obr. 6. Použité batymetrické vybavení při zaměřovací kampani na VN Nýrsko Fig. 6. Used equipment for bathymetric surveying campaign on Nýrsko water reservoir

Sběr dat na VN Nýrsko s využitím EcoMapper byl proveden celkem ve třech misích. Vzhledem k měření na vodárenské nádrži, kde by se osoby bez povolení neměly pohybovat, a ke klidným povětrnostním podmínkám byla zvolena varianta trasování na hladině. Data byla získána křižováním nádrže, jak je znázorněno na obr.7. Celkem bylo zaměřeno 37677 bodů, přičemž minimální zaměřená hloubka byla 0,43 m a naopak maximální 28,83 m. Předem plánovaná trasa a rychlost plavidla byla volena s ohledem na celkovou kapacitu akumulátoru tak, aby EcoMapper vždy bezpečně dorazil na předem určený cílový bod. Sběr dat prostřednictvím EcoMapper je prezentován na obr. 8.

Měřicí kampaň zařízeními RiverSurveyor M9, která byla připevněna na trimaranu a Hydroboardu II, byla použita pro mapování především príbřežních zón u př́toku do nádrže. Pro daný účel (měření batymetrie v mělkých vodách) disponuje vhodnými vlastnostmi predevším trimaran, kdy je možné pořizovat batymetrická data již od hloubek cca $20 \mathrm{~cm}$. Plavidlo disponuje vhodnou konstrukcí a splňuje vysoké manévrovací požadavky při mapování již zmíněných príbřežních zón. K vedení trimaranu slouží standardní dálkové ovládání, jehož hlavní předností je proporcionální řízení, což znamená, že je možné přidávat rychlost plynule nebo zvolit konstantní rychlost. Způsob ukotvení a vedení RiverSurveyoru M9 je vhodný na menší vodní plochy. V průběhu měřicí kampaně bylo pořízeno celkem 19602 bodů. Data byla získána křižováním oblasti hlavního prrítoku, přičemž vybraná ukázka pořizených dat je znázorněna na obr. 9. 


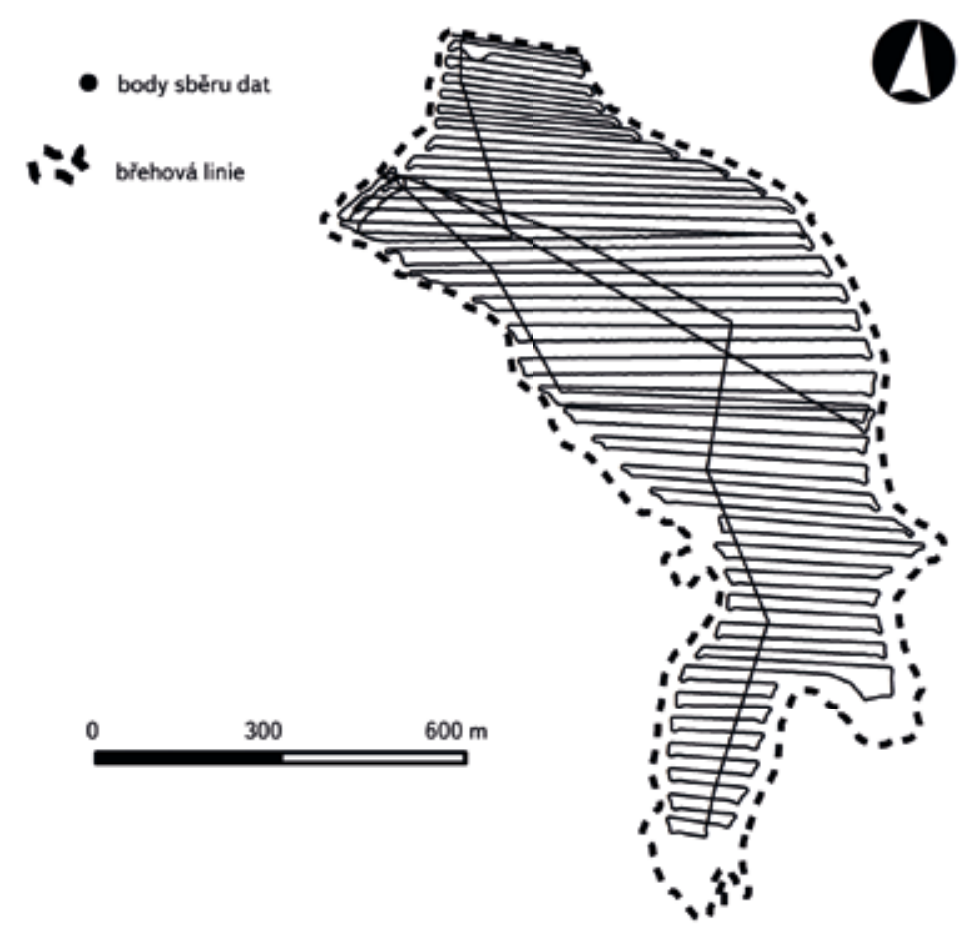

Obr. 7. Trasování na VN Nýrsko - EcoMapper

Fig. 7. Tracking on Nýrsko water reservoir - EcoMapper

Pro srovnávací analýzu bylo využito rovněž batymetrických dat Povodí Vltavy, s. p., která byla v roce 2010 pořízena měrícím člunem Joska - pořízeno bylo 516811 bodů, přičemž trajektorie pořízených transektů je prezentována na obr. 10. Člun Joska je laminátový kajutový člun Quicksilver typ 650 obr. 11. Na měřenou lokalitu je dopravován na podvozku za terénním autem. Ultrazvuková měřicí aparatura firmy Meridata ty MD500 pořizuje data v souřadnicích X, Y, H, která jsou transformována do systému S-JTSK. Možnosti nasazení jsou na přehradních nádržích, rybnících a vodních tocích, kde jsou splněny podmínky pro umístění na vodní plochu, podmínky dostatečného manipulačního prostoru či nutného ponoru. Technologie umožňuje měření hloubky sedimentů, klasické

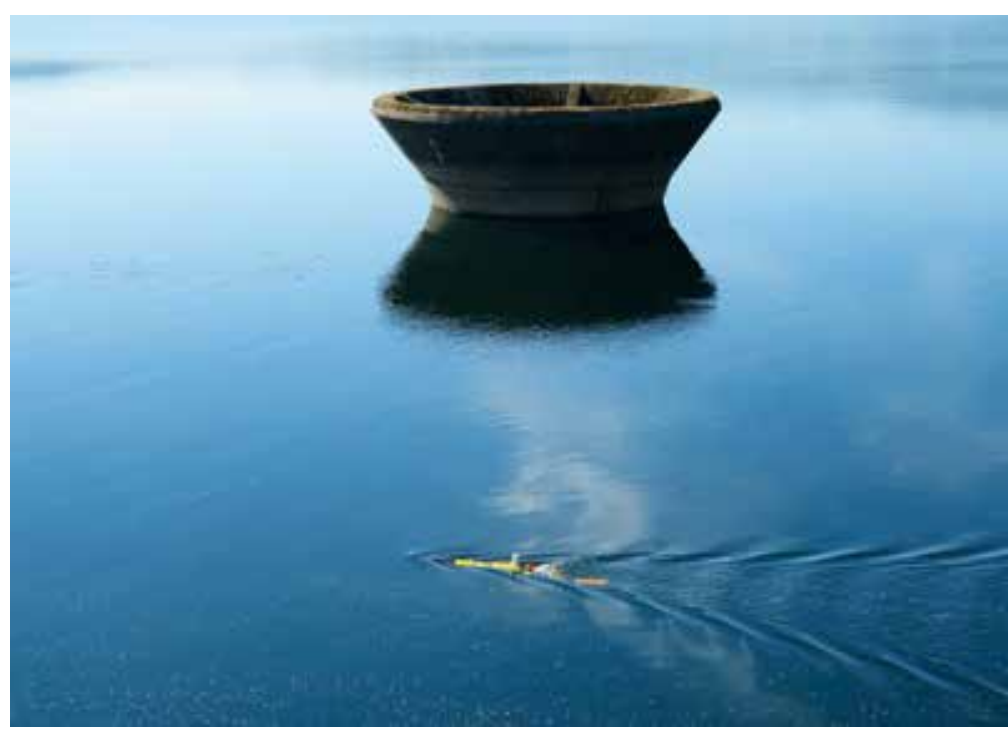

Obr. 8. EcoMapper při batymetrické misi v blízkosti sdruženého objektu Fig. 8. EcoMapper on a bathymetric mission near a clustered object

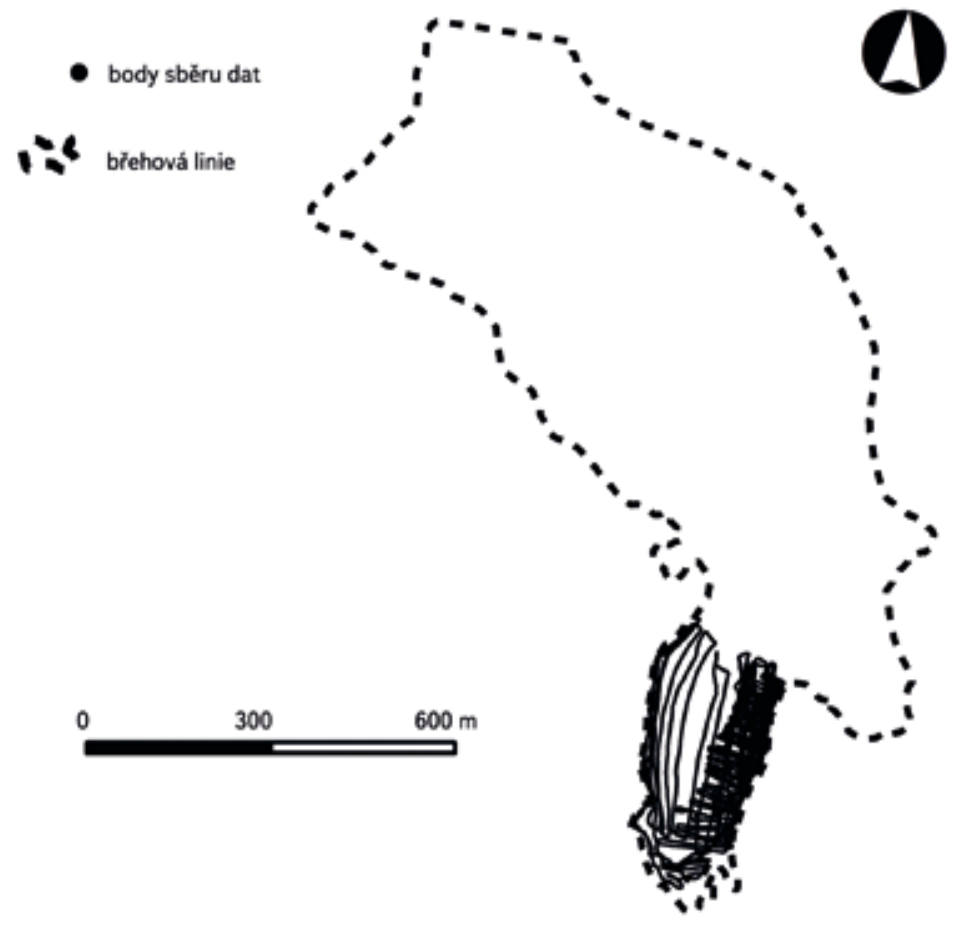

Obr. 9. Trasování na VN Nýrsko - RiverSurveyor M9

Fig. 9. Tracking on Nýrsko water reservoir - RiverSurveyor M9

měření hloubek i vyhledávání prípadných překážek. Minimální hloubka měření je vzhledem k ponoru člunu stanovena na $1 \mathrm{~m}$, ta maximální je uváděna až do $200 \mathrm{~m}$ pod hladinou [18].

\section{VÝSLEDKY}

Zpracování a vyhodnocení získaných dat proběhlo pomocí nástrojů geoinformačního systému ArcGIS od firmy ESRI. Prvním krokem bylo stažení dat z jednotlivých datových úložišt použivaných př́strojů pomocí připojení vzdálené plochy (Windows") ve formátu ASCII, v souřadnicovém systému WGS 84 (World Geodetic System 1984). Dále byla data transformována do souraadnicového systému S-JTSK. Pro získání DMR dna nádrže a blízkého okolí se nabízí celá řada interpolačních metod (IDW, TIN, Topoto Raster aj.). Na základě poznatků z předešlé prípadové studie zaměřené na batymetrické mapování [19] pak byla vybrána geostatistická metoda kriging, která při porovnání s výše uvedenými metodami dosahovala nejlepších výsledků.

Jako první byla provedena změna velikosti gridu získaných dat do buněk o velikosti hrany $5 \mathrm{~m}$. Z naměřených hodnot, které se protínaly s jednotlivými buňkami rastru, byla vypočítána průměrná hodnota buňky vstupující do interpolace. Takto připravená batymetrická data byla přepočítána na nadmořské výšky odečtením od aktuální kóty hladiny (519,5 m n. m.). Připravená batymetrická data byla spojena s výškovými údaji DMR 4G okolního terénu (buffer 500 m), pro účely lepšího zasazení do terénu a zpřesnění průběhu interpolace. Data DMR 4G byla využita na úkor presnějších dat DMR $5 G$ z důvodu nižších nákladů na pořízení a doplňující role těchto dat pro predkládanou případovou studii. Posledním krokem přípravy dat bylo odstranění batymetrických dat, která se vlivem změny velikosti gridu vyskytovala mimo zájmové území. Stejně tak byly odstraněny body z DMR 4G, které naopak do zájmového území zasahovaly. 
Analogicky jako pro data pořízená měřicí aparaturou EcoMapper, resp. RiverSurveyor M9, bylo postupováno i pro data poskytnutá od Povodí Vltavy, s. p. Takto získané DMR byly porovnávány mezi sebou, viz obr. 12 a 13, kde je prezentováno porovnání výsledné morfologie dna Joska vs. EcoMapper.

Získané výsledky dokládají shodu jednotlivých měřických přístupů (A) v případě pravidelné morfologie dna (pravidelné členitosti) vodní nádrže. $V$ prípadě proměnlivosti morfologie dna (B) je zřejmé, že $v$ prípadě EcoMapperu nejsou podchycena tato specifika, což vychází z hustoty pořizovaných dat $\checkmark$ rámci měřicí kampaně - viz srovnání obr. 7 a 9, resp. počtu pořízených bodů vstupujících do prípravy finálních DMR (EcoMapper 37 677, Joska 516 811). Obdobné poznatky byly získány i v prípadě porovnání výsledků z EcoMapperu, RiverSurveyoru a Josky, které jsou dokumentovány na obr. 13. Dílčí analýza byla provedena na vybraném príčném profilu u ústí vodního toku Úhlavy do VN Nýrsko. V dané lokalitě byla provedena detailní kampaň RiverSurveyorem M9, což dokládá i identifikace původního koryta vodního toku Úhlavy. Pưvodní koryto řeky Úhlavy bylo také velmi dobře zachyceno při měřicí kampani, kterou provedlo Povodí VItavy, s. p. Samotný širší záběr však opět dokládá vysokou shodu pořízených dat v rámci jednotlivých měřických zařízení.

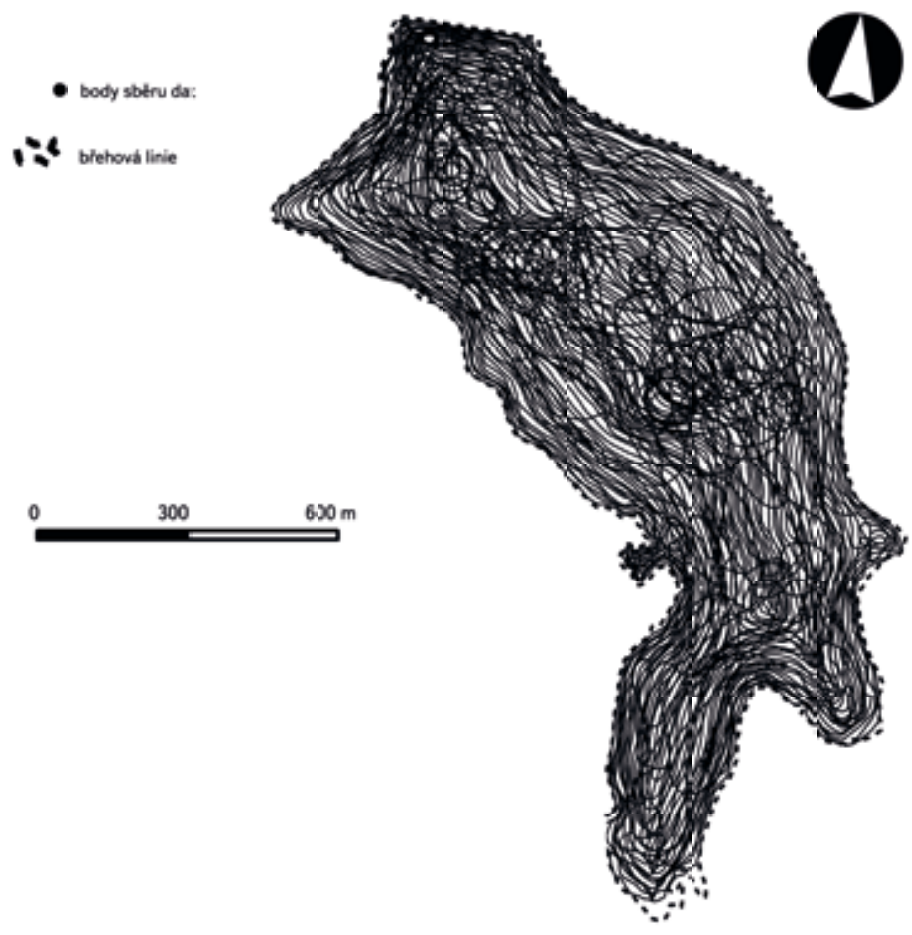

Obr. 10. Trasování na VN Nýrsko - Joska

Fig. 10. Tracking on Nýrsko water reservoir - Joska

\section{DISKUSE}

Bodová data zpravidla obsahují chyby, které ovlivňují výsledný model reliéfu dna vodní nádrže a navazující analýzy. Chyby mohou vznikat v různých fázích sběru i zpracování dat [20]. Jedna z nejzávažnějších chyb vyhodnocení batymetrických dat v morfologicky členitých vodních nádržích vzniká nedostatečnou hustotou měřených vzorků. Výsledný model reliéfu tak může být v těchto místech více ovlivněn interpolací než $\vee$ místech, kde jsou data $\vee$ husté síti. Naopak v malých vodních nádržích s miskovitým profilem není prioritou vysoká hustota odebraných vzorků, ale podrobně zaměřené předpokládané zlomové linie mezi břehy a dnem nádrže.

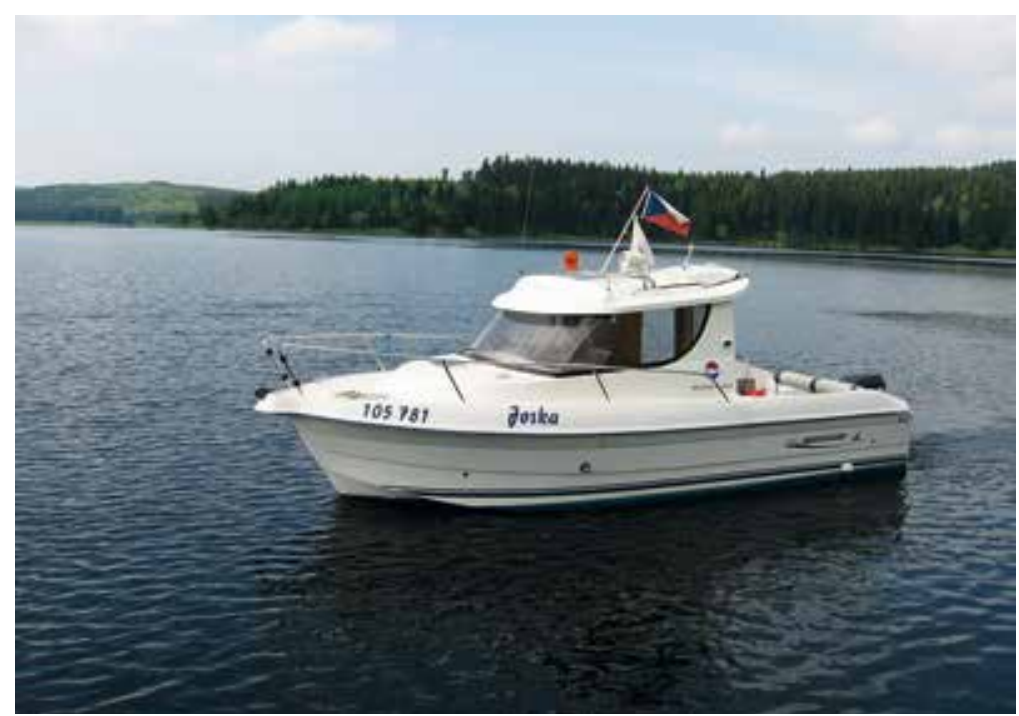

Obr. 11. Laminátový kajutový člun Joska - Quicksilver typ 650 [17]

Fig. 11. Laminated cabin boat Joska - Quicksilver typ 650 [17]

Přestože velkou roli v přípravě DMR hraje zvolený postup zpracování dat a vybraná interpolační metoda, není možné u morfologicky členitých nádrží jakoukoliv metodou nahradit nedostatečně "hustou" datovou sadu. Z toho vyplývá, že v prípadě potřeby detailního modelování morfologie, např. v zatopených lomech nebo při odhalování podvodního bohatství, je potřeba při využití výše popsaných, finančně dostupnějších technologií (single beam) zvýšit rozlišení zaměřených dat na maximum $v$ závislosti na velikosti požadovaného detailu. $V$ případě studií dynamiky sedimentu ve vodní nádrži, které budou reprezentativní v rádech $\mathrm{cm}$, je nutné identické trasování podle předem zvolené trajektorie pro všechna období [21]. Proto pro takovouto studii se jeví jako ideální prístup technologie EcoMapperu, kdy můžeme několikrát využít předem zvolenou trajektorii, a reálně tak podchytit změny $v$ mocnosti a dynamiku sedimentu v nádrži.

Alternativou pro časově náročné získávání dat jedním sonarovým paprskem jsou technologie mnoho-paprsčitého sonaru, jeho rozšířená verze $v$ podobě interferometrického sonarového systému, boční sonar, výložníkový systém,

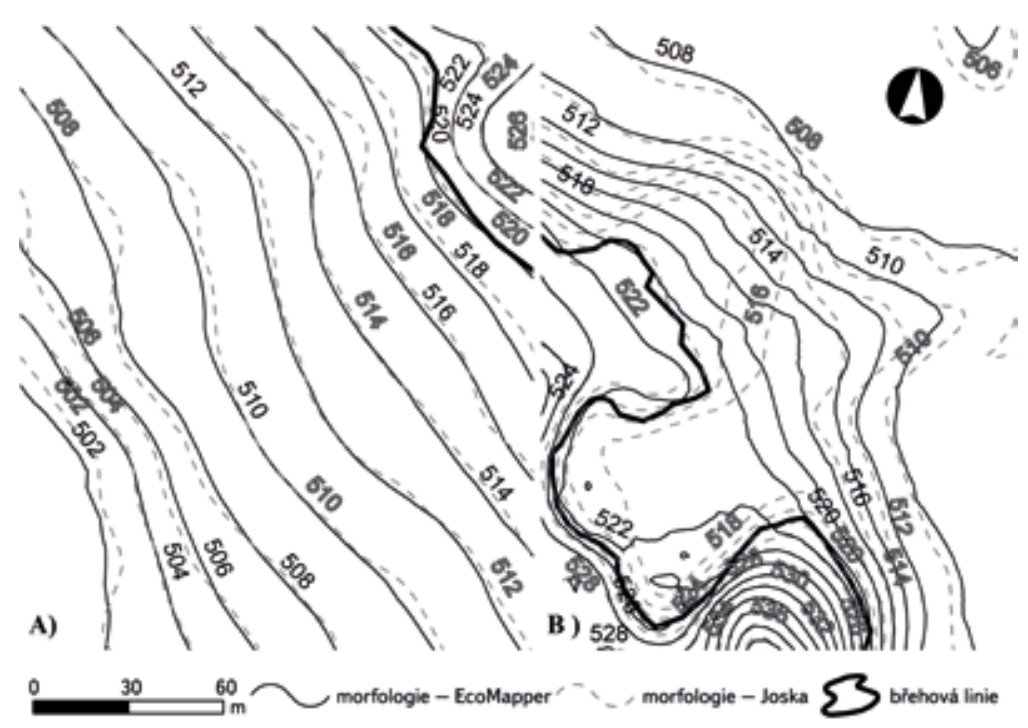

Obr. 12. Porovnání výsledné morfologie dna (Joska vs. EcoMapper)

Fig. 12. Comparison of final bottom morphology (Joska vs EcoMapper) 


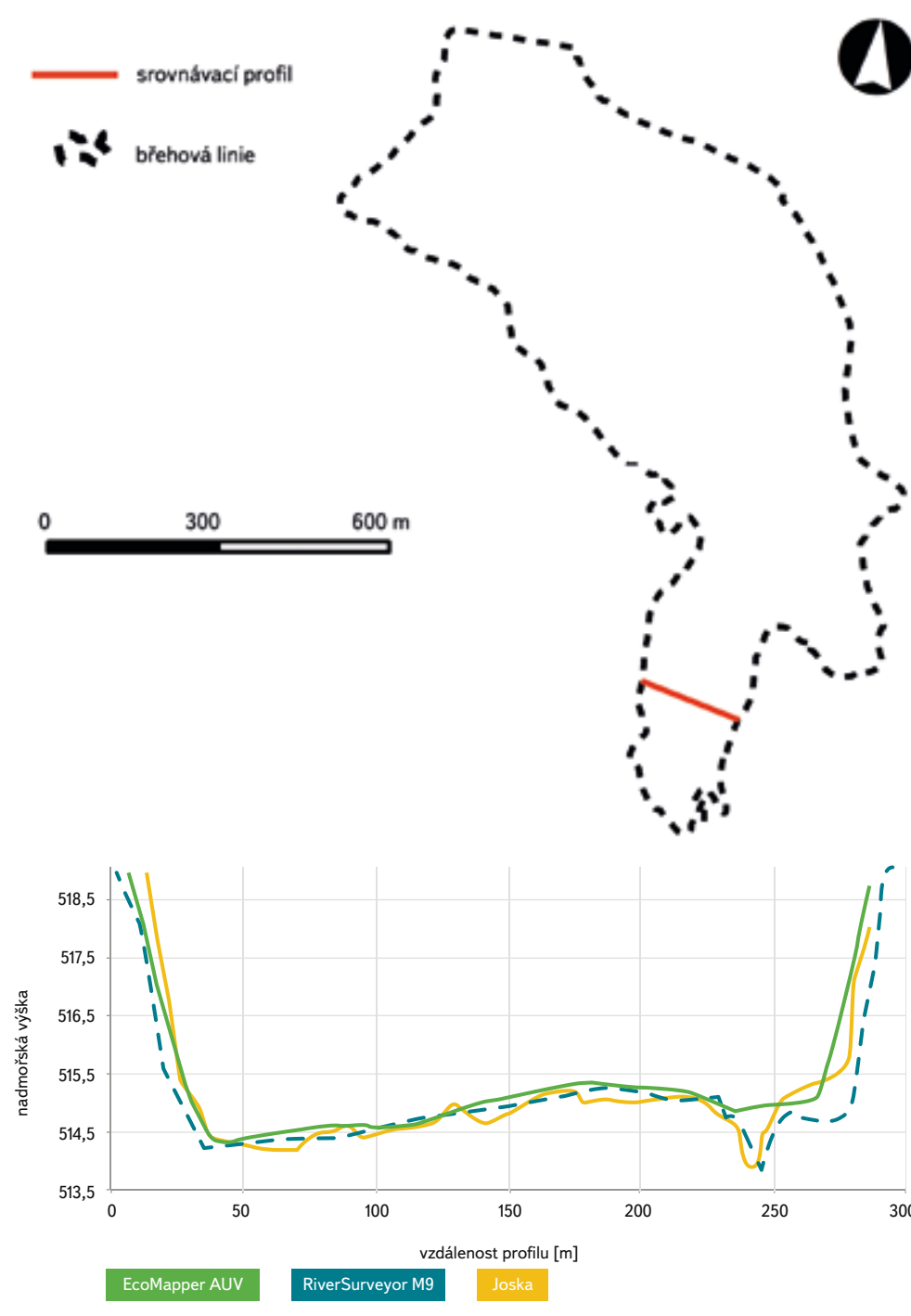

Obr. 13. Porovnání výsledné morfologie dna (EcoMapper vs. RiverSurveyor M9 vs. Joska) Fig. 13. Comparison of final bottom morphology (EcoMapper vs RiverSurveyor M9 vs Joska)

parasound sub-bottom profiling nebo duální LiDAR. Tyto technologie se velmi rychle rozvíjejí a jejich detailní popis Ize nalézt v certifikované metodice viz [22], kde se dále také autoři zabývají testováním v podmínkách ČR, cenovou dostupností testovaných technologií a možnými př́stupy pro batymetrická měření.

\section{ZÁVĚR}

Hlavním cílem testovacího měření na VN Nýrsko měřící aparaturou EcoMapper bylo vytvoření, resp. aktualizování 3D topografie vodní nádrže. Dalším cílem bylo ověřit deklarovanou využitelnost aparatury a její presnost v porovnání s daty získanými aparaturou RiverSurveyor M9 a daty poskytnutými od Povodí Vltavy, s. p.

Získané výsledky vykazují vysokou shodu z pohledu pořízených dat jednotlivými prístupy (RiverSurveyor M9, EcoMapper, Joska). Sběr dat prostřednictvím jednotlivých zařízení poskytuje řadu výhod, které předurčují jejich širší využití. Na druhé straně je nutné rovněž reflektovat omezení, která je nutné zohlednit při prováděných měřeních jednotlivými aparaturami. Výhody trimaranu Ize spatřovat především ve vysoké operabilitě a schopnosti měřit i v mělkých vodách, rychlém sestavení měřicí aparatury a mobilitě měření. Nevýhody spočívají především v časové náročnosti při pořizování datových sad - omezení na malé vodní nádrže. Zařizení EcoMapper naopak poskytuje zcela autonomní systém, který je vhodný nejen pro batymetrii sledování dynamiky sedimentů, ale i pro monitoring kvality vody, rozložení rychlostí aj. Poskytuje rovněž měření na místech, kde není dovoleno motorové plavidlo (vodárenské zdroje). Dále nabízí vysokou variabilitu z pohledu volby hustoty pořizovaných dat za předem jasně specifikovaných podmínek a zaručuje měření v předem určené trase.

Naměřené datové zdroje poskytují vysoce kvalitní podklad pro následné pokročilé analýzy $\vee$ geografických informačních systémech. Výsledné datové zdroje jsou následně využitelné při kvantifikaci množství sedimentů, projektové činnosti, matematickém modelování, případně pro zobrazování a prezentaci dat o jakosti vody v prípadě měřicí aparatury EcoMapper.

\section{Poděkování}

Tento príspěvek vznikl za podpory Technologické agentury ČR, projektu číslo TH02030399 Sledování množství a kvality sedimentů ve vodnich tocích a nádržích za účelem snižování znečištění z nebodových zdrojü. Přispěvek vznikl rovněž za podpory rešení projektu VEGA-2-0058-15 Analýza miery vplyvu sedimentov na interakciu povrchových tokov s podzemnými vodami pri implementácii progresívnych metód merania.

\section{Literatura}

[1] VRÁNA, K. a BERAN, J. Rybníky a účelové nádrže. Praha: ČVUT, 2013. ISBN 9788001040027.

[2] PIMENTEL, D. and BURGESS, M. Soil Erosion Threatens Food Production. Agriculture, 2013, 3, p. 443-463, doi:10.3390/agriculture3030443. [citováno: 21. 6. 2017]. Dostupné z: https://www.bmbf.de/files/ agriculture-03-00443.pdf

[3] WALLING, E.D. FOR THE INTERNATIONAL SEDIMENT INITIATIVE OF UNESCO-IHP. The impact of global change on erosion and sediment transport by rivers: current progress and future challenges. Paris, France: Unesco, 2009. ISBN 9789231041358. [citováno: 21. 6. 2017]. Dostupné z: http://unesdoc.unesco. org/images/0018/001850/185078E.pdf

[4] ISSAKA, S. and ASHRAF, A.M. Impact of soil erosion and degradation on water quality: a review. Geology, Ecology, and Landscapes, vol. 1, 2017, p. 1-11 [citováno: 21. 6. 2017]. Dostupné z: <http://www. tandfonline.com/doi/pdf/10.1080/24749508.2017.1301053?needAccess=true>

[5] United Nations Educational, Scietific and Cultural Organization, International Hydrological Programme. The Impact of global change on water resources: the response of unesco's international hydrology programme, 2011. [citováno: 21. 6. 2017]. Dostupné: <http://unesdoc.unesco.org/ images/0019/001922/192216e.pdf>

[6] BELL, F.G. Environmental geology: principles and practice. Malden, MA: Blackwell Science, 1998. ISBN 0865428751.

[7] KUBINSKÝ, D., FUSKA, J., WEIS, K. a LEHOTSKÝ, M. Zmeny akumulačného objemu vodných nádrží Velká Richňavská a Malá Richňavská. Acta Hydrologica Slovaca, 2013, roč. 14, č. 2, s. 402-413.

[8] BRÁZDIL, K. Projekt tvorby nového výškopisu území České republiky. Geodetický a kartografický obzor, 55/97, 2009, č. 7, s. 145-151.

[9] DOLANSKÝ, T. Lidary a letecké laserové skenování. Acta Universitatis Purkynianae, 99, Studia geoinformatica, Univerzita J. E. Purkyně v Ústí nad Labem, 2004, ISBN 80-7044-575-0.

[10] VIJAY, S. Autonomous underwater vehicles, Seminar on Autonomous Underwater Vehicles. Mandya: PESCE, 2011. [citováno: 12. 10. 2017]. Dostupné z: <http://www.scribd.com/doc/55826714/ Autonomous-Underwater-Vehicles>

[11] SOČUVKA, V. a VELISSKOVÁ, Y. Automatizované monitorovanie morfológie dna vodných tokov. Acta Hydrologica Slovaca, 2015, roč. 16, tematické číslo, s. 108-113.

[12] YSI (2011): ECOMAPPER, Autonomous Underwater Vehicle. [citováno: 10. 10. 2017]. Dostupné z: <http://www.watec.it/attachment.php?id_attachment=164>

[13] SonTek a Xylem brand, 2013. RiverSurveyor S5 / M9 System Manual.

[14] HRADILEK, V., BAŠTA, P., VIZINA, Š., MÁCA, P., and PECH, P. Verication of remote sensing data for measuring bathymetry on small water reservoirs. In: 15th International Multidisciplinary Sceintiic Geoconference SGEM 2015, Informatics, Geoinformatics and Remote Sensing 18. 06. 2015, Albena, Bulgaria. Sofia, Bulgaria: STEF92.

[15] HLAVÁČEK, J., ROUB, R., MARVAL, Š., HEJDUK, T., ČUBA, P., HRADILEK, V., NOVÁK, P., VYBÍRAL, T. a BUREŠ L. Technologie př́pevnění a stabilizace měricí aparatury RiverSurveyor M9 na trimaranu za účelem měreni batymetrie malých vodních nádrží, ověrená technologie. 61 str. ISBN 978-80-87361-71-9, smlouva o uplatnění ověřené technologie byla uzavrena s Lesy hl. m. Prahy. 
[16] RiverSurveyor M9 Hydroboard ADCP Rental. [citováno: 25. 7. 2018]. Dostupné z: https://www. fondriest.com/riversurveyor-m9-hydroboard-adcp-rental.htm

[17] SOČUVKA, V. a VELÍSKOVÁ, Y. Určenie batymetrie a kvality vody v nádrži pomocou AUV prístroja. Konferencia: Vplyv antropogénnej činnosti na vodný režim nižinného územia a fyzika vody $v$ pôde. Zemplínska šírava, 2.-4. červen, 2015, Slovenska republika.

[18] POVODí VLTAVY. Měřicí člun Joska. [citováno: 25. 7. 2018]. Dostupné z: http://www.pvl.cz/ vodohospodarske-informace/vymerovaci-lode/joska

[19] NOVÁK, P., ROUB, R., HRADÍLEK, V., MARVAL, Š., HEJDUK, T., VYBÍRAL, T. a BUREŠ, L. Batymetrický prístup pro stanovení zásobních kapacit, množství a dynamiky sedimentů vodních nádrží - pilotní studie Němčice. Vodní hospodárství, 2017, roč. 67, č. 9. ISSN 1211-0760

[20] KADLČÍKOVÁ, J. Testování a výběr interpolačních metod DMR v závislosti na typu georeliéfu Geomorphologia Slovaca et Bohemica, č. 2/2007: s. 14-18.

[21] ŠILJEG, A., LOZIĆ, S., and ŠILJEG, S. A comparison of interpolation methods on the basis of data obtained from a bathymetric survey of Lake Vrana, Croatia. Hydrol. Earth Syst. Sci., 2015, 19, p. 36533666. [online] [citováno: 11. 7. 2017] <https://doi.org/10.5194/hess-19-3653-2015>.

[22] NOVÁK, P., ROUB, R., VYBÍRAL, T., HLAVÁČEK, J., MARVAL, Š., HEJDUK, T. a kol. Nové technologie batymetrie vodních toků a nádrži pro stanovení jejich zásobnich kapacit a sledování množství a dynamiky sedimentü. Certifikovaná metodika. Praha: VúMOP, 2017, 62 s. ISBN 978-80-87361-81-8.

\section{Autoři}

Ing. Štěpán Marval|, 2

凶marval.stepan@vumop.cz

Ing. Tomáš Hejduk, Ph.D. ${ }^{2}$

凶hejduk.tomas@vumop.cz

Ing. Klára Dušková ${ }^{3}$

凶duskova@vrv.cz

Ing. Martin Tomek ${ }^{3}$

凶tomek@vrv.cz

Ing. Tomáš Vybíral, Ph.D. ${ }^{4}$

凶tomas.vybiral@georeal.cz

Ing. Radek Roub, Ph.D. ${ }^{1}$

凶roub@fzp.czu.cz

Ing. Yvetta Velísková, Ph.D. ${ }^{5}$

凶yvetta.veliskova@savba.sk

Ing. Valentín Sočuvka, Ph.D. ${ }^{5}$

凶socuvka@uh.savba.sk

Ing. Petr Dušek, Ph.D. ${ }^{5}$

凶dusek@uh.savba.sk

Ing. Jiří Hlaváček ${ }^{6}$

凶hlavacek@aquamonitoring.cz

'Česká zemědělská univerzita v Praze, Fakulta životního prostředí

${ }^{2}$ Výzkumný ústav meliorací a ochrany půdy, v. v. i.

${ }^{3}$ Vodohospodářský rozvoj a výstavba a. s.

${ }^{4}$ GEOREAL s. r. o.

'Ústav hydrológie SAV

${ }^{6}$ AQUAMONITORING, s. r. o.

Přispěvek prošel lektorským řízením.
BATHYMETRIC MEASUREMENT FOR

\section{DETERMINATION OF MORPHOLOGY}

OF WATER RESERVOIR BOTTOM

\section{MARVAL, S. ${ }^{1,2}$; HEJDUK, T. ${ }^{2}$; DUSKOVA, K. ${ }^{3}$; TOMEK, M. ${ }^{3}$; VYBIRAL, T. ${ }^{4}$; ROUB, R. ${ }^{1}$, VELISKOVA, Y. ${ }^{5}$; SOCUVKA, V. ${ }^{5}$; DUSEK, P. ${ }^{5}$; HLAVACEK, J. ${ }^{6}$}

${ }^{1}$ Czech University of Life Sciences Prague, Faculty of Environmental Sciences ${ }^{2}$ Research Institute for Soil and Water Conservation, p. r. i.

${ }^{3}$ Water Management Development and Construction

${ }^{4}$ GEOREAL s. r. o.

${ }^{5}$ Institute of Hydrology SAS

${ }^{6}$ AQUAMONITORING, s. r. o.

Keywords: sediment - bathymetric measurement -

EcoMapper - RiverSurveyor M9

Information and communication technologies are currently one of the decisive factors influencing economic and social development. Similar developments and trends in relation to information and communication technologies can be observed in the field of water management. To obtain relevant results in river hydraulics, determination of watercourse capacities and tanks, monitoring of the quantity and dynamics of sediments, are decisive the input data. The paper presents a summary of the results and experience from the performed bathymetric measurements on the Nýrsko water reservoir on the Úhlava River. Pilot Monitoring Campaigns have obtained data on water reservoir morphology using sophisticated instrumentation based on echo Souder RiverSurveyor M9 and EcoMapper AUV (Autonomous Underwater Vehicle). The paper presents the preparation and progress of field measurements, description of subsequent post processing of obtained data sets, comparative analysis, including comparison with data sets obtained using the Meridata ultrasonic measuring instrument, the MD500, installed on the Joska measuring boat operated by the Povodí Vltavy, State Enterprise. 